\title{
$\mathrm{CO}_{2}$ Capture Process Principles and Costs
}

\author{
P.H.M. Feron ${ }^{1}$ and C.A. Hendriks ${ }^{2}$ \\ 1 TNO Science and Industry, PO Box 342, 7300 AH Apeldoorn - The Netherlands \\ 2 Ecofys, PO Box 8408, 3503 RK Utrecht - The Netherlands \\ e-mail: paul.feron@tno.nl - c.hendriks@ecofys.nl
}

Résumé - Les différents procédés de capture du $\mathrm{CO}_{2}$ et leurs coûts - De grandes quantités de $\mathrm{CO}_{2}$ sont émises à pression atmosphérique par la production thermique d'électricité en particulier. Le principe de capture-stockage du $\mathrm{CO}_{2}$ offre des perspectives intéressantes pour limiter les émissions de gaz à effet de serre de cette filière. Le $\mathrm{CO}_{2}$ capturé doit ensuite être compressé avant les étapes de transport et de stockage.

Il y a trois catégories de procédés de capture du $\mathrm{CO}_{2}$ :

- les procédés postcombustion;

- les procédés précombustion;

- les procédés en oxycombustion.

Ces catégories sont toutes applicables aux combustibles fossiles et à la biomasse, moyennant des spécificités techniques en fonction de la nature du combustible. Elles mettent en œuvre plusieurs méthodes physicochimiques de séparation des gaz.

La capture du $\mathrm{CO}_{2}$ est l'étape la plus coûteuse de la chaîne capture-séquestration. Le bilan de cette chaîne est ici présenté pour différentes technologies de production de l'énergie, de capture et de transport du $\mathrm{CO}_{2}$. Huit étapes sont prises en compte, de l'extraction des combustibles fossiles à la séquestration $\mathrm{du} \mathrm{CO}_{2}$.

Abstract - $\mathrm{CO}_{2}$ Capture Process Principles and Costs - Carbon dioxide capture and storage (CCS) is an important concept to reduce greenhouse gas emissions, in particular from power plants. After $\mathrm{CO}_{2}-$ capture the $\mathrm{CO}_{2}$ needs to be compressed to achieve the right transport and storage conditions.

$\mathrm{CO}_{2}$ capture processes can be divided into three main categories:

- postcombustion processes;

- precombustion processes;

- oxy-combustion/denitrogenation processes.

These process categories are applicable to both fossil fuel and biomass. Several different physicalchemical gas separation methods used $\mathrm{CO}_{2}$-capture will be described.

The capture of $\mathrm{CO}_{2}$ is the most expensive step in the CCS-chain. A systematic approach to costs and emission of the chain capture-transport-sequestration of $\mathrm{CO}_{2}$ is presented, for different power generation technologies, capture and transport technologies. This involves eight steps, incorporating the complete chain from fossil fuel extraction to the production of the energy carrier and the storage of $\mathrm{CO}_{2}$. 


\section{INTRODUCTION TO $\mathrm{CO}_{2}$ CAPTURE}

\subsection{Relevance of $\mathrm{CO}_{2}$ Capture}

Carbon dioxide capture and storage (CCS) is gradually becoming an important concept to reduce greenhouse gas emissions, next to other options, such as, the use of renewable energy, the use of nuclear energy, energy efficiency improvements and switching from coal to gas firing. In CCS, $\mathrm{CO}_{2}$ is extracted at some point in the energy conversion train, depending on the type of energy technology used. It is then prepared for transport and stored in a suitable geological sink, where it is kept for a sufficiently long period. As such, CCS limits or altogether avoids the release of $\mathrm{CO}_{2}$ into the atmosphere as a result of combustion processes. It is thereby possible to sustain the use of fossil fuels (coal, gas and oil), while drastically reducing the $\mathrm{CO}_{2}$-emissions. In case of biomass based fuels the capture and storage of $\mathrm{CO}_{2}$ will result in a net decrease of $\mathrm{CO}_{2}$ in the atmosphere.

The overall, general CCS concept involves three steps:

- Capture of $\mathrm{CO}_{2}$. Large amounts of $\mathrm{CO}_{2}$ are emitted in diluted streams at atmospheric pressure, for instance, in flue gases from power stations, as the fuel is usually burned in air. To simplify the ensuing steps of transport and storage this needs to be concentrated. In general a near pure $\mathrm{CO}_{2}$ product at an absolute pressure of 100 bar needs to be produced by the capture process. Therefore also a compression step is needed to achieve the right transport/storage conditions.

- Transport of $\mathrm{CO}_{2}$. Transport of $\mathrm{CO}_{2}$ is needed as the emissions of $\mathrm{CO}_{2}$ will not necessarily be, at the same location as the storage site. A transport system is therefore needed to link the $\mathrm{CO}_{2}$-sources to the $\mathrm{CO}_{2}$-sinks.

- Storage of $\mathrm{CO}_{2}$. Storage of $\mathrm{CO}_{2}$ should be such that it remains isolated from the atmosphere for a suitably long period. The options for this are mainly in the underground, i.e. exhausted oil and gas fields, deep coal beds and aquifers. $\mathrm{CO}_{2}$ might also be chemically bound to certain rock materials, which is the means of $\mathrm{CO}_{2}$-control over geological time scales.

Various aspects and components of the CCS process chain have been researched over the past 15 years, both practically and theoretically. This has revealed that CCS can be a valuable part in the portfolio of technologies to reduce $\mathrm{CO}_{2}$ emissions. Both capture and transport of $\mathrm{CO}_{2}$ can be done using technologies which are commercially available. For instance, $\mathrm{CO}_{2}$-separation technologies are commonplace in the oil and gas industry. There is a need to adapt and optimise these separation technologies for CCS. As regards transport: various modes of $\mathrm{CO}_{2}$ transport are possible: pipeline, ship, tanker and the focus is on the infra-structural requirements. $\mathrm{CO}_{2}$-storage can be done in exhausted oil and gas fields, coal beds and aquifers. These technologies are at various stages of development. Injection of $\mathrm{CO}_{2}$ into oil fields is practiced already in the United States, under commercial conditions. The first commercial application of $\mathrm{CO}_{2}$ storage in an of-shore aquifer has been successfully been running since 1996 at the Sleipner gas field in Norway. An experimental study into the storage of $\mathrm{CO}_{2}$ in a coal bed, supported by the EC, is currently underway in Poland. A major challenge is to achieve societal acceptance of the concept of underground $\mathrm{CO}_{2}$-storage, for which several demonstration projects are currently underway.

As will be shown later on, capture of $\mathrm{CO}_{2}$ will determine the costs of the CCS-route. The contribution of capture to the overall cost will be around $75 \%$. It will also be shown that the production costs of electricity will increase by over $50 \%$. This shows that cutting the costs of capture is one of the most important issues in making the option acceptable to the energy industry.

$\mathrm{CO}_{2}$-capture processes or decarbonisation technologies can be divided into three main categories or general process routes:

- Postcombustion processes. Carbon dioxide is captured from a flue gas at low pressure $(1 \mathrm{bar})$ and low $\mathrm{CO}_{2}$ content $(3-20 \%)$, in general. The separation task is to remove $\mathrm{CO}_{2}$ from a mixture of mainly nitrogen and oxygen, but also the impact of flue gas impurities $\left(\mathrm{SO}_{x}\right.$, $\mathrm{NO}_{\mathrm{x}}$, particulates) needs to be taken into account.

- Precombustion processes. Carbon dioxide is captured from a gas mixture with predominantly $\mathrm{H}_{2}$ gas at high pressure (15-40 bar) and medium $\mathrm{CO}_{2}$-content (15-40\%) or carbon is produced directly from fossil fuels. Apart from the $\mathrm{CO}_{2} / \mathrm{H}_{2}$ separation, the feed gases also contain $\mathrm{CO}, \mathrm{H}_{2} \mathrm{~S}$ and sometimes other sulphur components.

- Denitrogenation processes. A concentrated stream of carbon dioxide can be produced by the exclusion of nitrogen before or during the combustion/conversion process. The difference with the previous process routes is that here the separation is targeted to produce oxygen from air (i.e. separation of oxygen from mainly nitrogen), thereby avoiding the need for $\mathrm{CO}_{2}$ separation. An additional advantage might be that in the same process all impurities are captured, as the process is essential free of flue gas.

These process categories are applicable to both fossil fuel and biomass based energy conversion processes (power plants and industrial plants). The process details will however be different for each type of fuels, and each type of energy conversion process. In addition to this, for coal based energy conversion processes the sulphur content of coal is an item, which impacts on the design, operation and costs of decarbonisation processes. This also applies for situations where bottom fuels, such as petcoke or asphalt are used. $\mathrm{CO}_{2}$ emissions from power production are around $30 \%$ of overall emissions. Power plants are the largest point sources of diluted $\mathrm{CO}_{2}$ and hence $\mathrm{CO}_{2}$-capture from power plant can have a large impact. Other large single point sources of 
diluted $\mathrm{CO}_{2}$ are furnaces and industrial boilers, and calcining processes. Power plants provide a convenient framework for comparison of options, but capture processes or decarbonisation technologies might be applied to any $\mathrm{CO}_{2}$ emission source.

\subsection{Postcombustion Decarbonisation}

The power station is a conventional one in which the fuel is mixed with air and burnt. Power is produced by gas turbines and/or steam turbines. The challenge here is to develop a $\mathrm{CO}_{2}$ separation process able to recover $\mathrm{CO}_{2}$ from the flue gas at an acceptable energy penalty and costs. The leading option is an absorption process using amine based solvents.

The general post-combustion process scheme is shown in Figure 1.

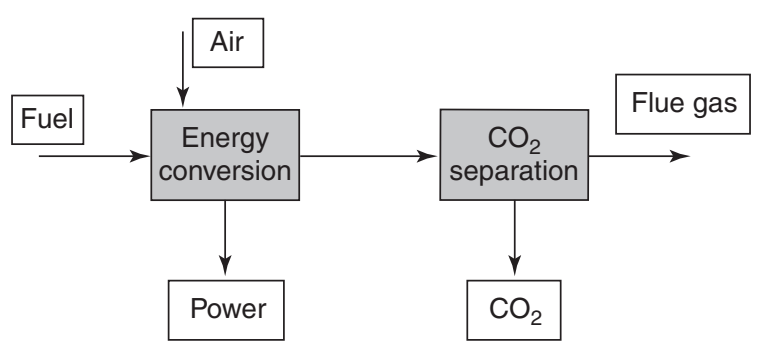

Figure 1

Postcombustion decarbonisation.

Postcombustion decarbonisation consists of two main process steps: an energy conversion step during which power is produced, followed by a $\mathrm{CO}_{2}$ separation process in which a concentrated stream of $\mathrm{CO}_{2}$ is produced.

\subsection{Precombustion Decarbonisation}

The fuel is first converted in a reformer or gasification process and the subsequent shift-reaction into a mixture of
$\mathrm{CO}_{2}$ and $\mathrm{H}_{2}$. The high pressure of this product gas stream facilitates the removal of $\mathrm{CO}_{2}$. The $\mathrm{H}_{2}$-product can then be burnt in a gas turbine, followed by a heat recovery and steam generation process or can be used in fuels cells. Although the pre-combustion technology results generally in relatively low parasitic power losses, a major issue here is the $\mathrm{H}_{2}$ combustion for a gas turbine. In the leading option is an absorption process is used for $\mathrm{CO}_{2}$-separation, in which the solvent can be a chemical one of physical one.

An alternative pathway is direct carbonisation giving solid carbon and $\mathrm{H}_{2}$. In this route the chemical energy content of carbon is not used. Hence the overall conversion efficiencies are expected to be lower.

Overall the precombustion decarbonisation may also contribute to (an accelerated) introduction of $\mathrm{H}_{2}$ as an energy carrier for stationary and mobile applications. As such it provides a link to an energy infrastructure based on $\mathrm{H}_{2}$ produced from renewable energy sources.

The general precombustion process scheme is shown in Figure 2.

Precombustion decarbonisation consists of three consecutive process steps: a fuel conversion step which produces a gas mixture from which $\mathrm{CO}_{2}$ can be removed as the second step and the final energy conversion process in which the power is produced.

\subsection{Denitrogenation}

In the route of denitrogenation the nitrogen present in the combustion air is kept separated from the carbon dioxide formed by the conversion process. In the leading option $\mathrm{O}_{2}$ is obtained in an air separation unit and combustion is carried out in an $\mathrm{O}_{2} / \mathrm{CO}_{2}$ atmosphere, obtained by the partial recycling of the nitrogen free flue gas. This is also referred as the oxy-fuel process.

The general denitrogenation process scheme is shown in Figure 3.

Denitrogenation consists of two consecutives process steps: an air separation step which results in an oxygen stream which is then used instead of air in the energy

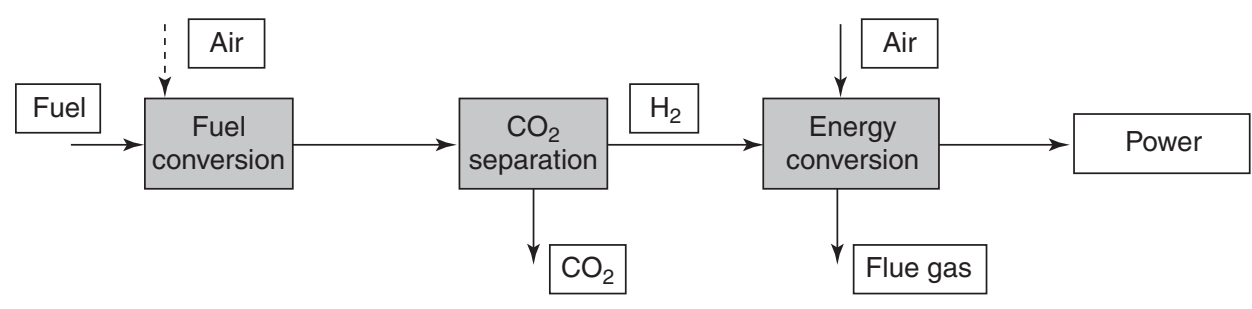

Figure 2

Precombustion decarbonisation. 


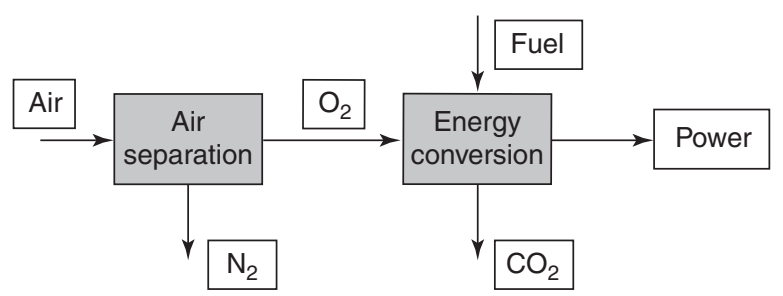

Figure 3

Denitrogenation.

conversion process. The resulting flue gas is then a high purity $\mathrm{CO}_{2}$ stream.

\section{CLASSIFICATION OF $\mathrm{CO}_{2}$-CAPTURE TECHNOLOGIES}

Capture of $\mathrm{CO}_{2}$ from energy conversion process generally means that at some point in the process $\mathrm{CO}_{2}$ will need to be separated, which is the case for post- and precombustion decarbonisation. Alternatively, the energy conversion process can produce a concentrated $\mathrm{CO}_{2}$-stream, provided nitrogen is not present during the $\mathrm{CO}_{2}$-formation. This is the principle of a denitrogenation process. In any case it is clear that overall $\mathrm{CO}_{2}$ capture or decarbonisation process will in general consist of a combination of energy or fuel conversion steps and separation steps.

Decarbonisation processes can involve several physicalchemical separation methods. These methods are:

- membranes, using selective barriers to separate gases;

- solvents, using absorption liquids to separate gases;

- sorbents, using selective particles to separate gases;

- cryogenic, using difference in points of condensation to separate gases.

In addition to these separation methods, fuels can also directly decarbonated and converted to inert carbon and hydrogen, avoiding the use of carbon in the combustion process. Also biological processes can be used to convert $\mathrm{CO}_{2}$ into biomass, which can then be used as a fuel. Finally, there is a number of enabling energy conversion technologies which are part of a decarbonisation process. It is particularly important to integrate the energy conversion technologies with the separation technologies for $\mathrm{CO}_{2}$ and $\mathrm{O}_{2}$ to achieve low cost and high efficiency capture routes.

TABLE 1

$\mathrm{CO}_{2}$-capture toolbox

\begin{tabular}{|c|c|c|c|}
\hline $\begin{array}{l}\text { Capture } \\
\text { method }\end{array}$ & $\begin{array}{l}\text { Postcombustion } \\
\text { decarbonisation }\end{array}$ & $\begin{array}{l}\text { Precombustion } \\
\text { decarbonisation }\end{array}$ & $\begin{array}{l}\text { Denitrogenated } \\
\text { conversion }\end{array}$ \\
\hline \multicolumn{4}{|l|}{$\begin{array}{l}\text { Principle of } \\
\text { separation }\end{array}$} \\
\hline Membranes & $\begin{array}{l}\text { - Membrane gas absorption } \\
\text { - Polymeric membranes } \\
\text { - Ceramic membranes } \\
\text { - Facilitated transport membranes } \\
\text { - Carbon molecular sieve membranes }\end{array}$ & $\begin{array}{l}\mathrm{CO}_{2} / \mathrm{H}_{2} \text { separation based on: } \\
\text { - Ceramic membranes } \\
\text { - Polymeric membranes } \\
\text { - Palladium membranes } \\
\text { - Membrane gas absorption }\end{array}$ & $\begin{array}{l}\cdot \mathrm{O}_{2} \text {-conducting membranes } \\
\text { - Facilitated transport membranes }\end{array}$ \\
\hline Adsorption & $\begin{array}{l}\text { - Lime carbonation/calcinations } \\
\text { - Carbon based sorbents }\end{array}$ & $\begin{array}{l}\text { - Dolomite, hydrotalcites } \\
\text { and other carbonates } \\
\text {-Zirconates }\end{array}$ & $\begin{array}{l}\text { - Adsorbents for } \mathrm{O}_{2} / \mathrm{N}_{2} \text { separation } \\
\text { - High temperature } \mathrm{O} 2 \text { adsorbent eg., } \\
\text { perovskites }\end{array}$ \\
\hline Absorption & $\begin{array}{l}\text { - Improved absorption liquids } \\
\text { - Novel contacting equipment } \\
\text { - Improved design of processes }\end{array}$ & $\begin{array}{l}\text { - Improved absorption liquids } \\
\text { - Improved design of processes }\end{array}$ & - Absorbents for $\mathrm{O}_{2} / \mathrm{N}_{2}$ separation \\
\hline Cryogenic & - Improved liquefaction & $\cdot \mathrm{CO}_{2} / \mathrm{H}_{2}$ separations & - Improved distillation for air separation \\
\hline Carbon extraction & Not applicable & - Direct decarbonisation & Not applicable \\
\hline Biotechnology & - Algae production & - High pressure applications & - Biomimetic approaches \\
\hline Energy conversion & $\begin{array}{l}\text { - Power cycles } \\
\text { - Combustion processes } \\
\text { - Gas turbine cycles } \\
\text { - Steam cycles }\end{array}$ & - Hydrogen in gas turbine combustors & - Combustion in $\mathrm{O}_{2} / \mathrm{CO}_{2} / \mathrm{H}_{2} \mathrm{O}$ atmosphere \\
\hline
\end{tabular}


A technology matrix can be built up, linking the three capture process routes with the different technological platforms. The matrix is filled with different technologies part of the overall $\mathrm{CO}_{2}$ capture process. The resulting $\mathrm{CO}_{2}-$ capture toolbox is shown in Table 1. It is a useful instrument for both mapping the relevant separation technologies and guiding future research initiatives in this area.

\section{COSTS AND EMISSIONS OF $\mathrm{CO}_{2}$ CAPTURE, TRANSPORT AND STORAGE}

The variety in technologies for $\mathrm{CO}_{2}$ capture as demonstrated in the previous sections can be quite large. In principle any kind of carbon containing fuel can be used in CCS systems. This may result in countless CCS systems by linking up the various chain elements. Each CCS chain will have its own emission factor and specific energy production costs. In this chapter a systematic approach to costs and emission of CCS systems is presented and the results of some relevant predefined CCS chains are compared. The technologies considered in the CCS system are all commercially available, but for the capture technologies in particular the scale of current applications is smaller than is needed for large scale power plants. The operation of these plants is governed by the existing regulations on health, safety and environment. There is no need to develop new regulations. Aspects such as the safety related to the handling of $\mathrm{CO}_{2}$ and the treatment of waste products are all dealt with through existing regulations. As regards the technology implementation the existing planning procedures can be followed. An environmental impact report will need to be included in these procedures, but this will be according to existing practices, as a capture plants not different from any other chemical plant.

\section{1 $\mathrm{CO}_{2}$ Emitted - Avoided, Captured}

The purpose of capture and storage of carbon dioxide is to reduce carbon dioxide emissions to the atmosphere. According to that view it is not the amount of carbon dioxide captured per unit of production (e.g. per kWh electricity) that is important, but it is the amount of carbon dioxide emission avoided. Due to the capture, transport and storage of $\mathrm{CO}_{2}$ additional energy input is required per unit of output. Because the plant with carbon dioxide capture produces the same output, but generates more carbon dioxide, the amount of carbon dioxide produced per unit of production will increase. As a result, the amount of carbon dioxide avoided is less than the amount of carbon dioxide captured. Figure 4 shows a graphical representation of these properties. As an example a coal-fired power plant is taken with $90 \%$ capture of the total generated carbon dioxide. In this example $0.86 \mathrm{~kg}$ $\mathrm{CO}_{2} / \mathrm{kWh}$ is captured and $0.70 \mathrm{~kg} \mathrm{CO} / \mathrm{kWh}$ is avoided. The lower amount of avoidance compared to captured also implies that the costs per tonne of carbon dioxide avoided will be higher than the costs per tonne of carbon dioxide captured.

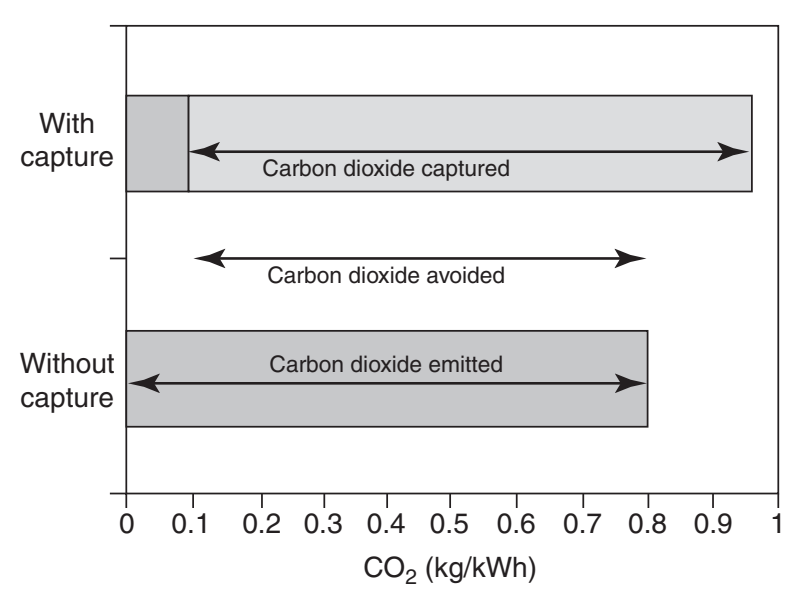

Figure 4

Graphical representation of the properties carbon dioxide emitted, carbon dioxide generated, and carbon dioxide avoided (example given for a coal-fired power plant).

\subsection{The Concept of the Production Chain}

Eight chain elements can be distinguished in the production chain of an energy conversion system with carbon dioxide capture and storage. This includes the four steps within the definition of the CCS system and three additional steps which are not directly belonging to the CCS activity but might be influenced by the application of the technology.

The eight chain elements and their mutual dependence are displayed in Figure 5. The production chain includes:

- Extraction and production of the fossil energy carrier. This means the extraction of coal, natural gas or oil.

- Transport of the fossil energy carrier. This means the transport of coal, natural gas or oil.

- Production of two products: the energy carrier (e.g. hydrogen or electricity) and the $\mathrm{CO}_{2}$. In a few concepts carbon instead of carbon dioxide is produced. A variety of production technologies can be used to produce these two products simultaneously. For instance:

- producing electricity with a coal-fired power plant and scrubbing the $\mathrm{CO}_{2}$ from the flue gases;

- firing natural gas with pure oxygen in a gas turbine producing electricity and a pure $\mathrm{CO}_{2}$ stream or reforming natural gas, and scrubbing the flue gas from a electricity or hydrogen production unit.

- Compression of the $\mathrm{CO}_{2}$. In practice in all cases carbon dioxide needs to be transported and is required at high pressure. Ship transport requires liquefaction. The $\mathrm{CO}_{2}$ is 


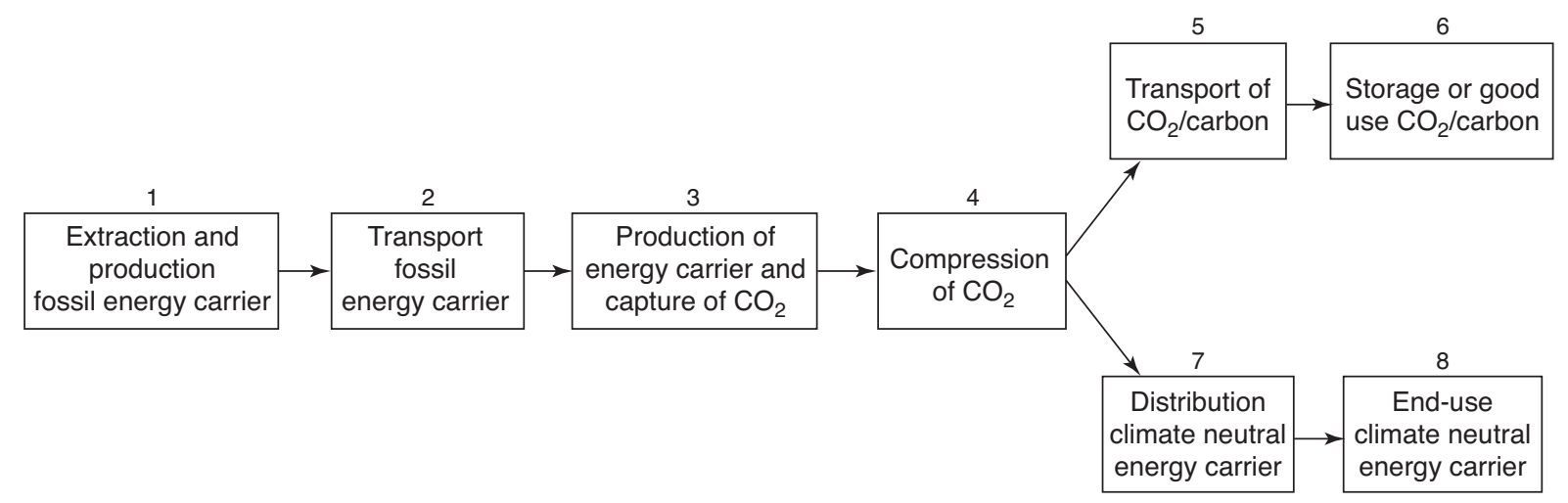

Figure 5

Chain elements in a CCS-system chain.

only at moderate pressure, e.g. $0.6 \mathrm{MPa}$ (although it has to be compressed as part of the liquefaction process).

- Transport and/or distribution of the $\mathrm{CO}_{2}$ or carbon.

- Storage of the $\mathrm{CO}_{2}$ or carbon. In this step the $\mathrm{CO}_{2}$ is stored. Examples are the use of $\mathrm{CO}_{2}$ to extract methane from coal layers not economically accessible for coal mining through Enhanced Coal Bed Methane (ECBM), storage of $\mathrm{CO}_{2}$ in aquifers and empty gas fields.

- Transport and distribution of the produced energy carrier.

- End-use of the produced energy carrier. This means the use of the energy carrier by the end-user.

\subsection{Electricity Production Technologies}

In this chapter we evaluate a number of electricity production technologies without and with carbon dioxide capture regarding their emission and cost performance. Information on emission and costs presented in this chapter is obtained from Audus (2001), Bolland et al. (1992, 2001), Chiesa et al. (1999), Clemens and Wit (2001), Condorelli et al. (1991), Dave et al. (2001), Foster and Wheeler (2000), Hendriks (1994), Hendriks et al. (2002), Hendriks et al. (2003), Mariz (1995, 1999), Parsons (1996), Pruschek and Gottlicher (1996), Simbeck (1999), and Stork (2000).

The production technologies are either based on coal or on natural gas. The evaluation is based on the total electricity production chain, thus including the extraction and transportation of fossil fuels, the capture of the carbon dioxide from the energy conversion processes, and the compression, transport and storage of the captured carbon dioxide. Table 2 shows the list of electricity production technologies that are evaluated. In the table also the abbreviations are given which will be used throughout the

TABLE 2

List of electricity production technologies

that are evaluated in this study on emission and cost performance

\begin{tabular}{l|l}
\hline Production technology & Abbreviation \\
\hline Natural gas-fired combined cycle & NGCC-none \\
\hline$\ldots$..including postcombustion $\mathrm{CO}_{2}$ capture technology & NGCC-postcomb \\
\hline$\ldots$..including precombustion $\mathrm{CO}_{2}$ capture technology & NGCC-precomb \\
\hline Natural gas-fired conventional (boiler) power plant & NG conv-none \\
\hline$\ldots$.including postcombustion $\mathrm{CO}_{2}$ capture technology & NG conv-postcomb \\
\hline Coal-fired conventional (boiler) power plant & Coal conv-none \\
\hline$\ldots$. including postcombustion $\mathrm{CO}_{2}$ capture technology & Coal conv-postcomb \\
\hline Integrated coal gasifier combined cycle & IGCC-none \\
\hline$\ldots .$. including precombustion $\mathrm{CO}_{2}$ capture technology & IGCC-precomb \\
\hline
\end{tabular}


text. Table 3 presents the (financial) conditions under which the electricity production chain is evaluated.

TABLE 3

Standardised electricity production chain conditions

\begin{tabular}{l|l}
\hline Capture rate & $90 \%$ \\
\hline Outlet pressure compressor & $12 \mathrm{MPa}$ \\
\hline Compression energy & $416 \mathrm{~kJ} / \mathrm{kg}$ \\
\hline Transport distance to $\mathrm{CO}_{2}$ storage & $100 \mathrm{~km}$ \\
\hline Depreciation factor & $11 \%$ (discount rate $10 \%$, lifetime $25 \mathrm{y})$ \\
\hline Storage location & Depleted natural gas field \\
\hline Coal price & $1.5 € / \mathrm{GJ}$ \\
\hline Natural gas price & $3.0 € / \mathrm{GJ}$ \\
\hline
\end{tabular}

\subsection{Emission of Greenhouse Gases in the Electricity Production Chain}

For the electricity production technologies shown in Table 2, the total emissions and emission per chain element are determined. The results of the calculation are shown in Figure 6. It can be seen that the actual energy conversion step represents the largest contributor to the emission of the total electricity production chain. When coal is used, also substantial amounts of greenhouse emissions (methane) occur during the extraction of the fuel. The indirect emissions from the power consumed during the compression of the captured carbon dioxide also contribute to the total emissions.

\subsection{Cost of Electricity and Cost of Avoidance}

The production costs for the energy carrier can be split into three parts:

- investments: once-only costs for the production facility, the $\mathrm{CO}_{2}$ storage facility and the infrastructure;

- operation and maintenance costs (O\&M);

- fuel costs.

By choosing the appropriate technical lifetime and discount rate the costs for the production of one unit electricity is determined by:

$$
\text { cost }=\frac{(\text { annuity factor } \times \text { investments })+O \& M+\text { fuel cost }}{\text { delivered energy }}\left[\frac{\text { euro }}{G J} \text { or } \frac{\text { euro }}{k W h}\right]
$$

$N B$ : The discount rate and the depreciation period determine annuity factor.

The investments are depreciated over the lifetime of the investments. It is assumed that installations will be depreciated in 25 years at a discount rate of $10 \%$.

The emission reduction costs may also be expressed in avoidance costs, i.e. the costs to avoid the emission of $1 \mathrm{t}$

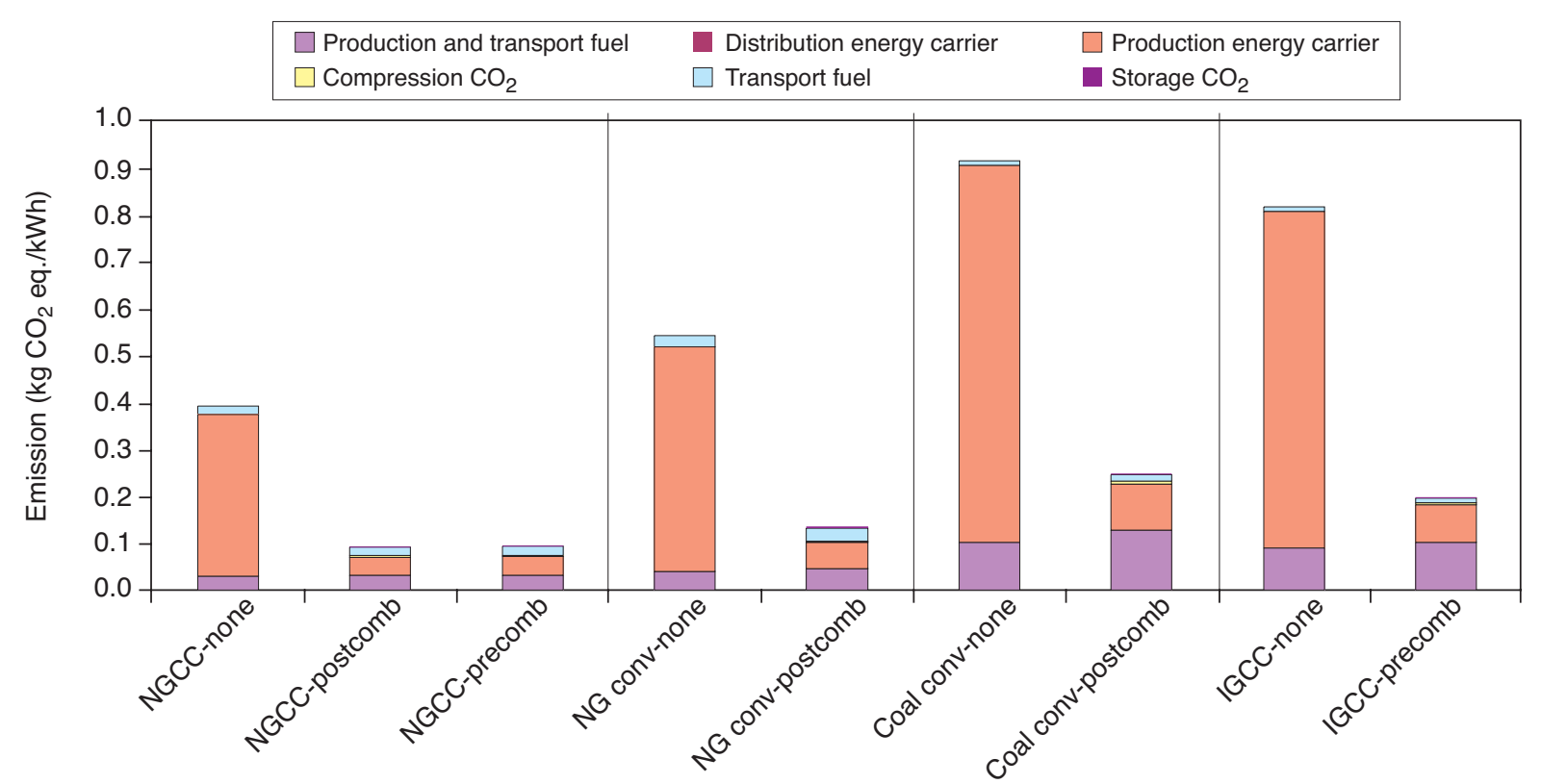

Figure 6

Emission breakdown of greenhouse gases for various electricity production routes. The emissions are given in $\mathrm{CO}_{2}$-equivalent using 100-year GWP. Assumed is that the power requirements for compression is obtained from the power plant with capture facilities. 
$\mathrm{CO}_{2}$-eq. The costs of $\mathrm{CO}_{2}$ avoidance (relative to a reference plant with no $\mathrm{CO}_{2}$ capture) is the economic parameter most widely presented. The avoidance costs are calculated as:

$\operatorname{cost} \mathrm{CO}_{2}$ avoided $=\frac{\text { ost }_{C C S}-\text { cost }_{\text {reference }}}{\text { emission factor } \text { reference }_{\text {emission factor }} \text { CCS }}\left[\frac{\text { euro }}{t \mathrm{tO}_{2}}\right]$

Figure 7 shows the electricity production costs for the technologies listed in Table 2. The production costs for natural gas-based technologies are dominated by the fuel price, whereas the costs for coal-based technologies are dominated by the investment costs for the power production facilities. The cost increase for technologies with carbon dioxide capture is mainly subject to the costs associated with the capture of carbon dioxide. Costs for transport, compression and storage of the captured carbon dioxide are less relevant. If carbon dioxide capture and storage is applied to electricity production the costs increase by 0.015 to 0.030 euro/kWh.

Figure 8 depicts the avoidance costs for the technologies listed in Table 2 . The costs are relative to the same electricity production technology without a capture facility (light bars)

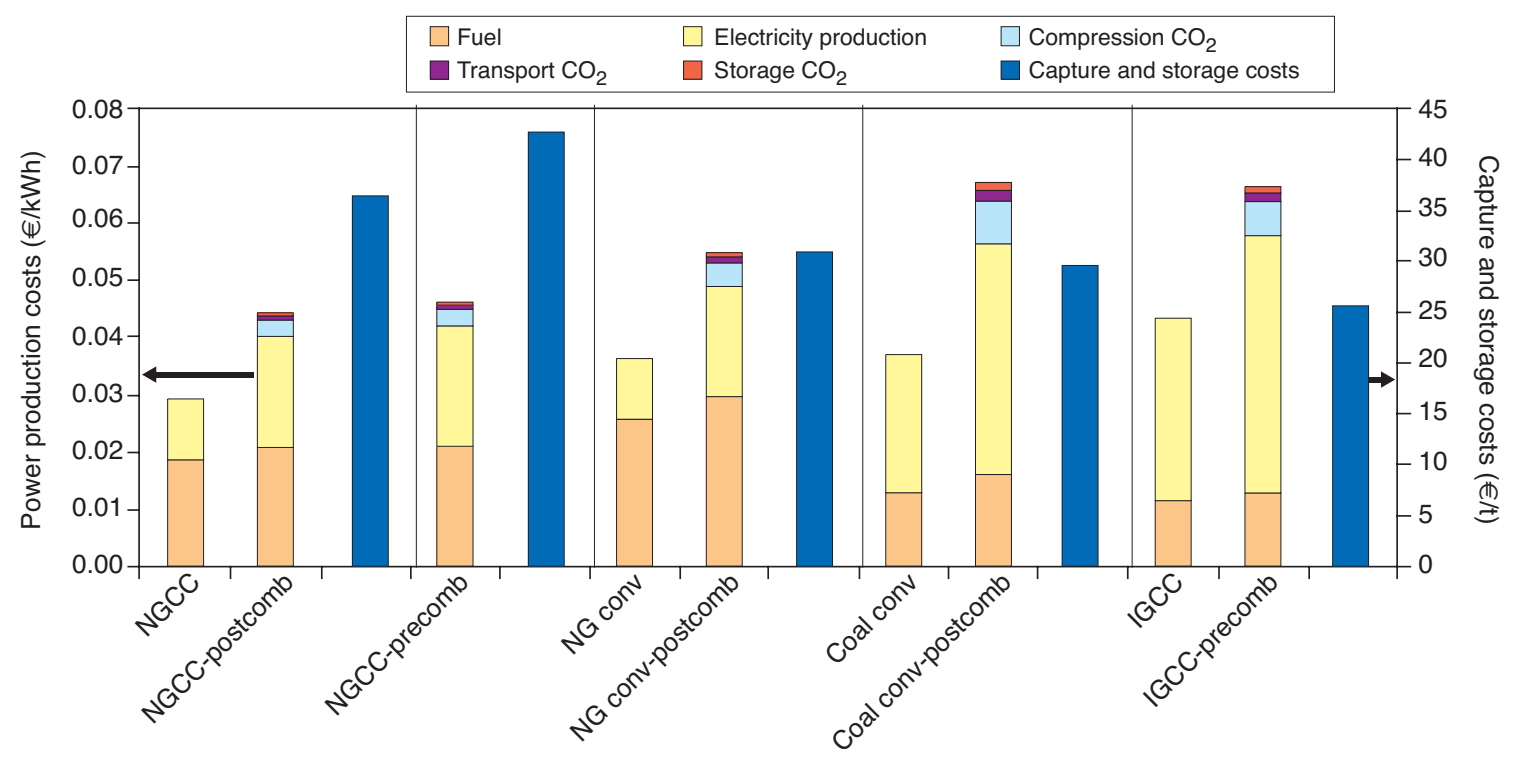

Figure 7

Electricity production costs for various electricity production technologies.

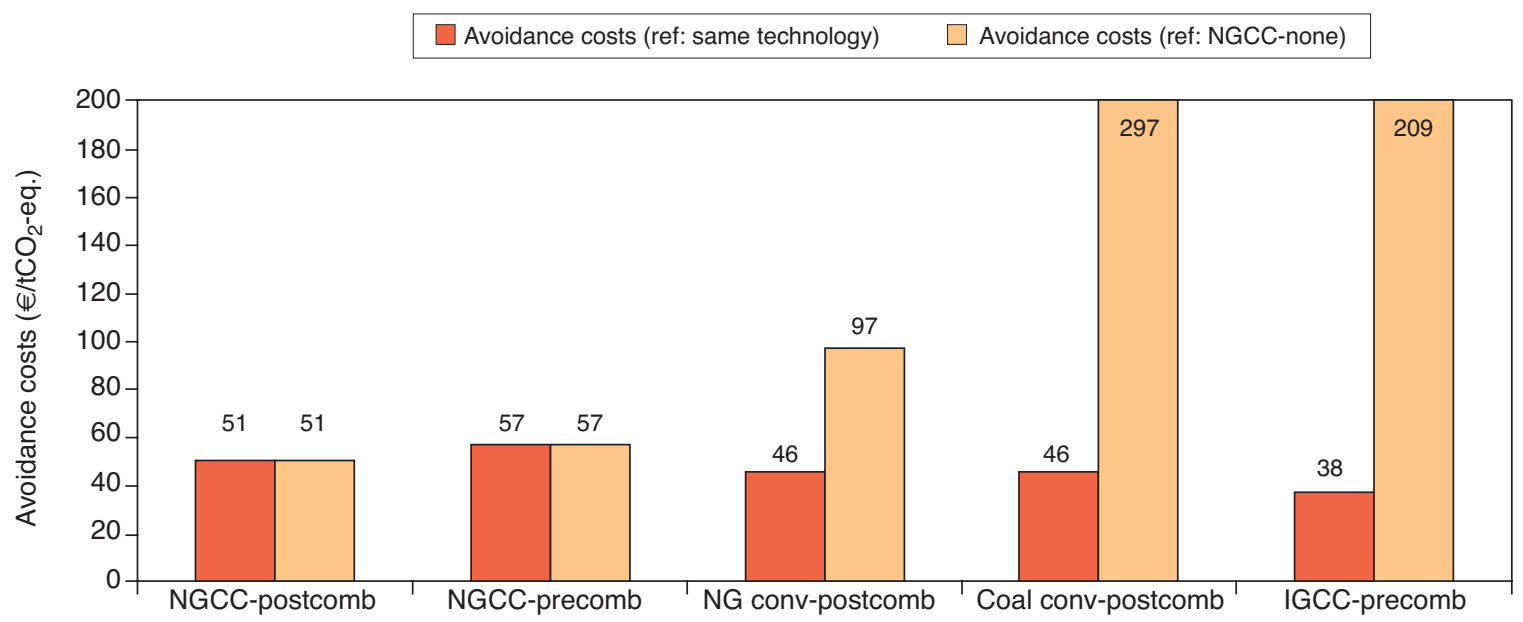

Figure 8

The greenhouse gas emission reduction costs for the various electricity production technologies. The references are the same electricity production technology (dark bar) and the NGCC-none (light bar). 
and relative to an NGCC-none (dark bars). The costs range from about 40 to $60 € / \mathrm{t} \mathrm{CO}_{2}$-eq. avoided when the same technology (but without capture of carbon dioxide) is the reference. In the figure it can be seen that the avoidance costs for coal-fired power plants is less than for the natural gasbased systems. However, the avoidance costs for coal-based systems increase substantially (to $200 € / \mathrm{t} \mathrm{CO}_{2}$-eq. avoided or more) when the NGCC technology is chosen as the reference technology.

\section{ACKNOWLEDGEMENTS}

Information in this chapter is based on the results of the study EC CASE concerning the further developmental requirements for carbon dioxide capture and storage. We would like to gratefully acknowledge $D G$ Environment of the European Commission for their support in the study.

\section{REFERENCES}

Audus, H. (2001) Leading Options for the Capture of $\mathrm{CO}_{2}$ at Power Stations. In: Greenhouse Gas Control Technologies (GHGT-5), D. Williams et al. (eds.), 91-96.

Bolland, O., Undrum, H. and Myhre-Nielsen, M. (1992) New Concepts for Natural Gas Fired Power Plants which Simplify the Recovery of Carbon Dioxide. Energy Convers. Mgmt., 33, 5-8, 467-475.

Bolland, O. (2001) Natural Gas Fired Power Cycles with Integrated $\mathrm{CO}_{2}$ Capture. In: Proceedings of the 5th Greenhouse Gas Control Technology Conference, Cairns, Australia.

Chiesa, P., Consonni, S. and Lozza, G. (1999) A Comparative Analysis of IGCCs with $\mathrm{CO}_{2}$ Sequestration. In: Proceedings of the 4th Greenhouse Gas Control Technology Conference, Interlaken, Switzerland.

Clemens, T.G. and Wit, K. (2001) Zero Emission Power Generation Power Plant Concepts and $\mathrm{CO}_{2}$ Injection into Gas Fields, Shell Technology EP, Rijswijk, Netherlands.

Condorelli, P., Smelser, S.C. and Mc Cleary, G.J. (1991) Engineering and Economic Evaluation of $\mathrm{CO}_{2}$ Removal from Fossil-fuel Power Plants. In: Coal Gasification Combined Cycle, 2, Electric Power Research Institute. Report IE-7365.

Cough, C. and Shackley, S. (2003) Public and Stakeholder Perceptions of Carbon Capture and Storage, Report prepared for the GESTCO Project, Tyndall Centre for Climate Change Research.
CRUST (2001) Legal Aspect of Underground $\mathrm{CO}_{2}$ Bufferstorage (in Dutch), Legal Taskforce CRUST. Report, Novem, Sittard, the Netherlands, www.crust.nl

Dave, N.C., Duffy, G.J., Edwards, J.H and Lowe, A. (2001) Economic Evaluation of Capture and Sequestration of $\mathrm{CO}_{2}$ from Australian Black Coal-fired Power Stations, CSIRO Energy Technology and CRC for Black Coal Utilisation. In: Greenhouse Gas Control Technologies (GHGT-5), D. Williams et al. (eds), 173-178.

Foster and Wheeler (2000) Precombustion Decarbonisation, IEA GHG R\&D Programme. Report PH2/19.

Hendriks, C.A, Farla, J. and Blok, K. (1992) Verwijdering en opslag van $\mathrm{CO}_{2}$ bij elektriciteitsopwekking (Capture and Storage of $\mathrm{CO}_{2}$ at Power Generation (in Dutch), Department of Science, Technology and Society, Utrecht University, Utrecht, The Netherlands.

Hendriks, C.A. (1994) Carbon Dioxide Removal from Coal-fired Power Plants, Kluwer Academics Publisher, Dordrecht, The Netherlands.

Hendriks, C.A., Harmelink, M. and Cuelenaere, R. (2002) Financial Incentives For Climate Neutral Energy Carriers, Ecofys and Ministry of Housing. Spatial Planning and Environment, Utrecht, The Netherlands.

Hendriks, C.A., van der Waart, A.S., Byrman, C. and Brandsma, R. (2003) GESTCO: Sources and Capture of Carbon Dioxide, prepared for the GESTCO project, Ecofys, Utrecht, the Netherlands.

Mariz, C.M. (1995) Carbon Dioxide Recovery: Large Scale Design Trends. Sixth Petroleum Conference at the South Saskatchewan Section, The Petroleum Society of CIM, Regina Canada.

Mariz, C.M. (1999) Recovery of $\mathrm{CO}_{2}$ from Flue Gases: Commercial Trends, Canadian Society of Chemical Engineers Annual Meeting, Saskatchewan, Canada.

Parsons (1996) Carbon Dioxide Recovery in Air-Blown and Oxygen-Blown Integrated Gasification Combined Cycle Power Plants, IEA GHG R\&D Programme. Report PH2/4.

Pruschek, R. and Gottlicher, G. (1996) Concepts of CO, Removal from Fossil-fuel Based Power Generation Systems, Universitat GH Essen.

Simbeck, D. (1999) A Portfolio Selection Approach for Power Plant $\mathrm{CO}_{2}$ Capture, Separation and R\&D Options. In: Proceedings of the 4th Greenhouse Gas Control Technology Conference, Interlaken, Switzerland.

Stork (2000) Leading Options for the Capture of $\mathrm{CO}_{2}$ Emissions at Power Stations. Study of Stork Engeneering Consultancy for IEA Greenhouse Gas R\&D Programme, The Netherlands, Report $\mathrm{PH} 3 / 14$.

Final manuscript received in May 2005 